\title{
Money, Output and Inflation in Bangladesh: A Test of Cointegration and Causality
}

\author{
Md. Shahnewaz Khan \\ Assistant Professor, Department of Economics, Jatiya Kabi Kazi Nazrul Islam University, Trishal, Mymensingh, \\ Bangladesh
}

\begin{abstract}
This paper examines the relative impacts of money on economic growth and inflation in the economy of Bangladesh. It uses monthly data of Consumer Price Index, M2 multiplier, and industrial production index of Bangladesh from the Global Economic Monitor database of the World Bank. Using Johansen Co-integration and Vector Error Correction framework, the study finds that there is one cointegration relationship among these three variables. The Granger Causality results suggest that increased money multiplier has significant impacts on economic growth but non-significant impacts on inflation thus rejecting the neutrality of money in the Bangladesh economy over the study period. The results also suggest that the impact of money is unidirectional on economic growth.
\end{abstract}

Keywords: neutrality of money, economic growth, cointegration, causality

DOI: $10.7176 / \mathrm{JESD} / 10-10-19$

Publication date:May $31^{\text {st }} 2019$

\section{Introduction}

The role of money in determining output and price occupies a central position in macroeconomic literature. There has been a great deal of controversy regarding the influence of monetary policy and the trade-offs associated with increased money supply on real economic growth and macroeconomic stabilization. The Classical view holds that a change in the money supply is associated with a corresponding change in the price level. According to Keynesian economics, expansionary monetary policy is an important tool to increase the effective demand by increasing spare capacity utilization. Monetarists, on the other hand, deny the role of policies and insist on the long run neutrality of money (Froyen 2005; Crowder 1998; Rangarajan \& Arif 1990; Bannock et al. 2009). The prime focus of this paper is to examine the relative influence of money in raising the level of real output and inflation in Bangladesh. In other words, the objective is to examine if inflation is a monetary phenomena and if money is neutral in the long run in the economy of Bangladesh.

\section{Literature Review \\ 2.1 Context}

Monetarists view that the supply of money has predominant influence on the movement of nominal income. In the short run, it has substantial effect on the real economic variables like output and employment, although it has no impact on the real variables in the long run except raising the price level. They also view that the instability in the economy is caused by government policies. Thus they suggest a rule based monetary policy for attaining a stable economy. On the other hand, Keynesians propose for a discretionary monetary policy in order to attain high economic growth, particularly if the economy is characterized by less than full employment equilibrium (Froyen 2005; Crowder 1998; Bannok et al. 2009).

Monetarist prediction about the role of money in the current economic activities has led to the development of a good number of empirical studies concerning the direction of causality between money and income. Using PostWar quarterly data (1947-1969) of money stock and current dollar GNP, Sims (1972) found unidirectional causality running from money to income. He argued that the usual practice of using money as exogenous in the distributed lag regression of income on money in the Quantity Theory framework is justified. The results of Sims support the monetarist view that the stock of money is the principal determinant of current economic activity in an economy. Using the same methodology developed by Sims (1972), Barth \& Bennett (1974) conducted an empirical test of the causal link of money and income for the Canadian economy over the period 1957-1972. In contrast to Sims, they did not find any evidence of unidirectional causality running from money to income or from income to money. Rather, they found evidence of feedback relationship between money and income thus suggesting that money is not the principal agent in determining the real economic activity. Another study by Williams et al. (1976) also expressed doubt about the presence of unidirectional causality from money to income. Using UK data since 1958I to 1971-III, they found some evidence of unidirectional causality from nominal income to money and also from money to prices. They suggested that the direction of causality is less clear-cut than which was suggested by Sims and that there could be a possibility of simultaneous causality rather than the unidirectional causality. 
There are two main schools of thought that explain the causes of inflation in the developing countries. The structuralists argue that the prime cause of inflation in the developing countries is the structural constraints of their economies, such as agricultural weaknesses, persistent balance of payment deficits, and other structural rigidities (market imperfections, socio-economic and political constraints, etc.). In contrast, the monetarists view that inflation is essentially a monetary phenomenon. This view is based on the Quantity Theory of Money which suggests that money and inflation has a one-to-one correspondence (Taslim 1982; Bilquees 1988; Chowdhury et al. 1995). They view that inflation results not from the structural constraints of these countries but from the inappropriate monetary and fiscal policies like government deficit financing, expansionary credit policies, etc. (Taslim 1982). Rami (2010) examined the causal relationship between money, prices, and output in India using annualized data from 1951 to 2005 . He applied the Granger Causality approach and claimed that the Indian case strongly validates the monetarist prediction that money plays an active role in determining nominal income and prices. Using quarterly data of real GDP and Consumer Price Index (1975:I-2003:IV), Kemal (2006) found that the inflation in Pakistan is a monetary phenomenon. Malik (2006) also found similar result in the case of Pakistan.

\subsection{Empirical Studies - Bangladesh}

To analyze the cause of inflation in Bangladesh, Taslim (1982) conducted a study in line with the monetariststructuralist controversy. The study is perhaps the earliest in its genre in Bangladesh. He constructed three empirical models to test the cause of inflation in Bangladesh - a purely structuralist model which analyzed the role of agricultural and foreign exchange bottlenecks in creating inflation; a purely monetarist model which analysed the impact of monetary aggregate measures on inflation; and a hybrid model that combines both the structural constraints and money supply into the equation and then analyzed their respective roles to create inflation. He argued that neither the pure monetarist nor the pure structuralist model completely explain the inflation in Bangladesh and the hybrid model performs best, thus suggesting the relevance of both structural and monetary factors explaining inflation in Bangladesh.

Jones \& Sattar (1988) conducted a study using data from 1974-1985 to analyze the relationship between money, inflation and output in Bangladesh. They used three variables - (a) change in the money supply $\left(\mathrm{M}_{1}\right.$ and $\left.\mathrm{M}_{2}\right)$; (b) change in the CPI (base year 1980) to represent inflation; and (c) change in the industrial production mix (base year 1980) to represent output. Using a Granger Causality framework, they suggested that the inflation in Bangladesh is not a purely monetary phenomenon and that the non-monetary factors have significant impacts on the inflation in Bangladesh. They also suggested that the money is not neutral in the economy of Bangladesh.

Using quarterly data (1974-92), Chowdhury et al. (1995) claimed that the inflationary process in Bangladesh cannot be explained solely by the monetarist or structuralist explanation. Their multivariate VAR system included the following variables $-\mathrm{M}_{1}$ and $\mathrm{M}_{2}$ as the monetary aggregates, industrial production index as the output variable, consumer price index as the inflation measure, and the foreign exchange rate variable. They did not find any clearcut cause and effect relationship between money supply and inflation in Bangladesh. They claimed that the monetary policy in Bangladesh has a significant unidirectional causal impacts on the real output.

Mujeri et al. (2009) conducted another study to measure the inflationary pressures in Bangladesh. They used annualized data of real GDP, changes in the consumer price index, and broad money $\left(\mathrm{M}_{2}\right)$ during 1980-2008 time periods. Their empirical work tested the forecasting performance of the $\mathrm{P} *$ model for the economy of Bangladesh which combines the long run determinants of price level based on the classical quantity theory of money and short run changes in inflation. They highlighted the significance of the non-monetary factors in explaining the inflation in Bangladesh.

Using annualized data of money supply $\left(\mathrm{M}_{2}\right)$ and income (nominal GDP) during 1974-2008, Hossain (2011) concluded that there is a stable long term (co-integrated) relationship between money and income in Bangladesh. Using an error correction approach, the study also found evidence of feedback relationship between these two variables in the short run. The study highlighted the need for undertaking monetary policy for achieving output goals in an economy like Bangladesh.

Another study by Bhuiyan (2012) estimated the effects of monetary policy in Bangladesh using an open economy Bayesian structural VAR approach and using monthly data covering the time periods 1994-2009. They argued that some external variables like remittances, exports, oil prices, and non-fuel commodity prices influence the monetary policy and the real economy of Bangladesh despite the fact that Bangladesh is a small open economy. Their structural VAR approach identified a monetary policy function of Bangladesh and allowed simultaneous interactions of a number of domestic and foreign variables comprising the following variables - (i) monetary aggregate $\left(\mathrm{M}_{2}\right)$; (ii) three months treasury bills rate; (iii) nominal exchange rate of Bangladeshi Taka against US 
dollar; (iv) monthly consumer price index; (v) industrial production index; (vi) remittances; (vii) exports; (viii) non-fuel commodity prices; and (ix) oil prices. Consistent with the findings of the new open economy macroeconomics (NOEM) literature, the study found that monetary policy shocks has immediate effect on interest rate and exchange rate in Bangladesh; but it has effects on industrial production with a lag of over half a year and on inflation with a lag of more than one year.

\section{Methodology and Data}

The study uses monthly data of Consumer Price Index (CPI), M2 multiplier and industrial production of Bangladesh during June 1995 - July 2009 from the Global Economic Monitor database of the World Bank ${ }^{1}$. The CPI data is a widely used measure of inflation which is seasonality adjusted. The money (M2) multiplier is defined as the broad money to monetary base ratio, which indicates the ability of the commercial banks to create money. A high value of the index implies an increase of money supply and vice-versa. The industrial production data is seasonality adjusted at constant 2010 US \$. The index is used as a measure of the real economic activity thus an increase in the index shows the growth of the real sector. I have used the log specifications of each variable. The three variables are defined as - 'lcpi' for log of CPI; 'lM2'for log of M2 multiplier; and 'lipro' for log of industrial production.

The problem in dealing with the time series regression is that most time series are non-stationary (i.e., they exhibits time varying mean, variance, and covariance). In such cases, applying simple OLS leads to spurious regressions. Establishing valid relationship among different non-stationary time series requires the existence of cointegration among them. If two time series $y_{t}$ and $x_{t}$ are non-stationary but their linear combination is stationary, then we can say that these two series are cointegrated. Consider the following model -

$$
y_{t}=\alpha+\beta x_{t}+u_{t} \ldots \ldots \ldots \text {..... (1) }
$$

where $y_{t}$ and $x_{t}$ represent two non-stationary time series variables and $u_{t}$ is white noise error term. Now if $u_{t}$ is stationary, then its linear combination $\left(y_{t}-\alpha-\beta x_{t}\right)$ will also be stationary; in other words, we can say that $y_{t}$ and $x_{t}$ are cointegrated. If there is a cointegrating relationship across variables, we can say that there is a valid long run relationship among them. Then their short run relationships (the deviation from the long run equilibrium) can be expressed in terms of an error correction model (Engle \& Granger 1987; Gujarati et al. 2009). The Error Correction Model (ECM) of these two variables can be represented as follows -

$$
\Delta y_{t}=\alpha_{0}+\alpha_{1} \Delta x_{t}+\alpha_{2}\left(y_{t-1}-\beta_{0}-\beta_{1} x_{t-1}\right)+\varepsilon_{t}
$$

where $\alpha_{1}$ indicates the short run impact to restore equilibrium and $\alpha_{2}$ indicates the speed of adjustment at which the equilibrium is restored. The idea of the ECM can be extended to a vector of multiple variables, known as the Vector Error Correction Model (VECM).

In this paper, I have used multivariate Cointegration and Vector Error Correction Model (VECM) to test the long and short run relationships between money supply, economic growth, and inflation in Bangladesh. First, I check for the stationary of these three variables and check whether they are white noise (stationary) or unit root (nonstationary) process. Second, I test the existence of cointegration and the number of cointegrating relationships in the model. Third, I run the unrestricted and restricted vector error correction model. Finally, I use the Granger causality technique to see the direction of causality between money, growth, and inflation.

\section{Unit Roots and Stationarity}

Figure 1 and 2 plots the data of the three variables over time. The plots of these variables show that they all have some general increasing trends thus indicating that their means might be different across time (non-stationary).

\footnotetext{
${ }^{1}$ http://data.worldbank.org/data-catalog/global-economic-monitor, accessed on 01 May 2015
} 
Figure 2: Plots of CPI and industrial production

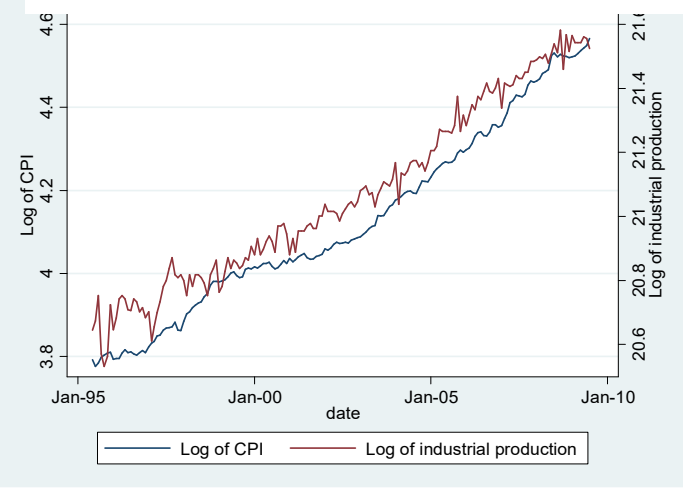

Figure 2: Plots of CPI and M2 multiplier

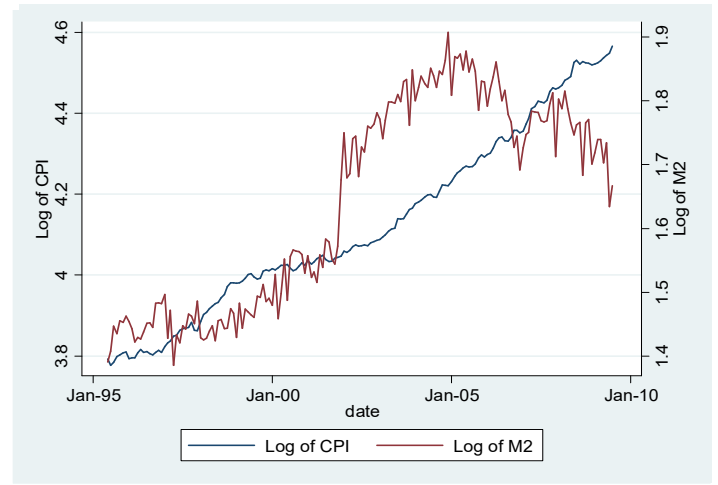

However, I have used two formal tests to examine the existence of unit roots - Augmented Dickey Fuller (ADF) and Phillips-Perron (PP) tests. The ADF test assumes autocorrelation of the error term of the random walk model and thus augments the Dickey Fuller (DF) equation by adding the lagged values. The ADF test thus takes the following regression -

$$
\Delta Y_{t}=\beta_{1}+\beta_{2} t+\theta Y_{t-1}+\gamma \sum_{i=1}^{k} \Delta Y_{t-i}+\varepsilon_{t} \ldots \ldots \ldots \ldots
$$

where $\Delta Y_{t}=Y_{t}-Y_{t-1}$ and $k=$ number of lags in the dependent variable, $\varepsilon_{t}$ is white noise, $\beta_{l}$ is drift and $t$ is the trend term. The null hypothesis in the ADF test is that there is presence of unit root. In other words, if we cannot reject the null hypothesis that $\theta$ in the equation is zero, then there is evidence of unit root. The PP test uses nonparametric methods to account for the autocorrelation of the disturbance term. Both the ADF and PP tests can be conducted at different specifications - random walk; random walk with drifts, and random walk with drift and a deterministic trend (Gujarati et al. 2009; Greene 2006). I have conducted these tests by taking 12 lags and with and without trend specifications. The null hypothesis in both these tests is that there is unit root. The results of these tests are presented in Table 1. It shows that the ADF and PP statistics of all these variables in both specifications are lower than their critical values at $1 \%, 5 \%$ and $10 \%$ levels in their absolute terms, thus suggesting that these variables are non-stationary.

Table 1: Results of ADF and PP tests (at 12 lags)

\begin{tabular}{cccccc}
\hline Variable & \multicolumn{2}{c}{ ADF statistic } & \multicolumn{2}{c}{ Phillips-Perron test statistic } & Decision \\
& Without trend & With trend & Without trend & With trend & \\
\hline lcpi & 0.835 & -1.095 & 1.894 & -1.215 & $\begin{array}{c}\text { Non- } \\
\text { stationarv } \\
\text { Non- } \\
\text { lM2 }\end{array}$ \\
lipro & -1.458 & -0.419 & -1.633 & -1.775 & $\begin{array}{c}\text { continnarr } \\
\text { Non- } \\
\text { ctationars }\end{array}$ \\
\hline
\end{tabular}

Note: The ADF critical values are $-3.49,-2.89$, and -2.58 at $1 \%, 5 \%$, and $10 \%$ levels are respectively (without trend). They are respectively $-4.02,-3.44$, and -3.14 (with trend). The critical values for the PP test are $-3.49,-2.89$, and -2.58 respectively at $1 \%, 5 \%$, and $10 \%$ levels (without trend). They are respectively $-4.02,-3.44$, and -3.14 (with trend).

\section{Cointegration}

The Johansen technique has been used to test for the existence of cointegration. This is a widely used technique for testing cointegration in multivariate analysis (Johansen 1988). The first step in the Johansen procedure requires identifying the lag order of the underlying Vector Autoregressive model. Table 2 reports the result of VECM lag lengths. The suggested lag order is 2 according to Hannan and Quinn's information criterion (HQIC) and Schwarz Bayesian information criterion (SBIC). However, according to Akaike's final prediction error (FPE) and Akaike's information criterion (AIC), the suggested lag is 3. I have followed the HQIC and SBIC lag order and thus choose a lag length of 2 for estimating the VECM. 
Table 2: Results of selection-order criteria

\begin{tabular}{ccccccccc}
\hline lag & LL & LR & df & $\mathrm{p}$ & FPE & AIC & HQIC & SBIC \\
\hline 0 & 444.962 & & & & $9.8 \mathrm{e}-07$ & -5.32485 & -5.30202 & -5.26861 \\
1 & 1215.57 & 1541.2 & 9 & 0.000 & $1.0 \mathrm{e}-10$ & -14.5008 & -14.4095 & -14.2758 \\
2 & 1244 & 56.861 & 9 & 0.000 & $8.0 \mathrm{e}-11$ & -14.7349 & $-14.5751^{*}$ & $-14.3412^{*}$ \\
3 & 1253.11 & $18.236^{*}$ & 9 & 0.033 & $8.0 \mathrm{e}-11^{*}$ & $-14.7363^{*}$ & -14.508 & -14.1739 \\
4 & 1261.2 & 16.182 & 9 & 0.063 & $8.1 \mathrm{e}-11$ & -14.7254 & -14.4286 & -13.9942 \\
\hline
\end{tabular}

Sample: 5-170; no of observations 166

The Johansen test involves the identification of the number of ranks $(r)$ in the VECM. The null hypothesis is that there is no more than ' $r$ ' cointegrating relationship. Table 3 shows that the trace statistics are higher at $r=0$ (but lower at $\mathrm{r}=1$ ) than their $5 \%$ critical values in all three specifications. It suggests that we can reject the null that there are no $(\mathrm{r}=0)$ cointegrating relationship but cannot reject the null that there are no more than one co-integrating relationship in the VECM. Thus it can be concluded that the maximum rank of the cointegrating VECM is 1 and that there is one cointegrating relationship between money supply, inflation, and industrial production in the VECM.

Table 3: Result of Johansen test for cointegration

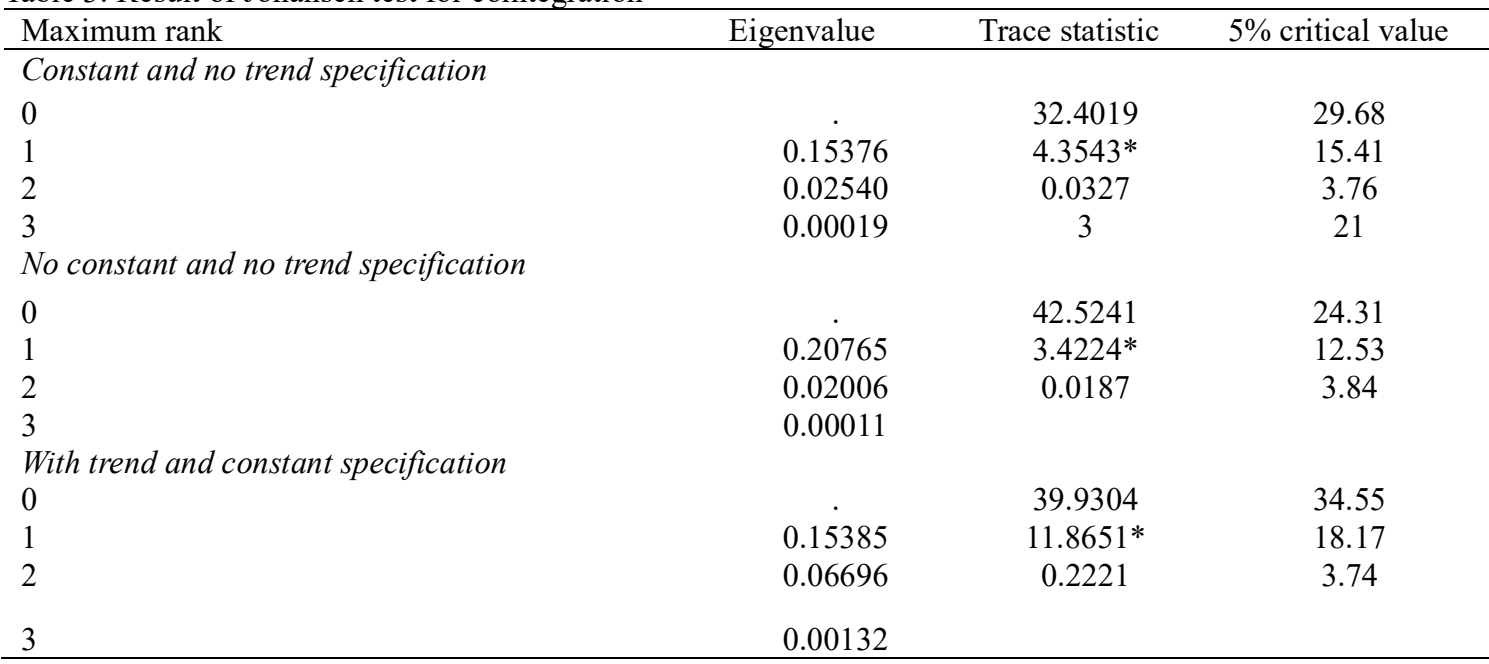

Sample: $3-170 ;$ No of observation=168; Lags=2

\section{Vector Error Correction Model}

The Johansen approach considers the following equation as the VECM -

$$
\Delta y_{t}=\alpha\left(\beta^{\prime} y_{t-1}+\mu+\rho_{t}\right)+\sum_{i=1}^{p-1} \Gamma_{i} \Delta Y_{t-i}+\gamma+T t+\varepsilon_{t} \ldots \ldots \ldots \ldots
$$

where $\alpha$ and $p$ are oom $\mathrm{K}^{-\mathrm{r}}$ rank matrices, $y_{t}$ is a $\mathrm{K}^{\cdots} \mathrm{I}$ vector or variabies; $\mu$ and $\rho$ are $\mathrm{r}^{\cdots} \mathrm{I}$ vectors of parameters and $\gamma$ and $T$ are $\mathrm{k}^{*} 1$ vectors of parameters. While the original VAR considers $p$ lags in $y$, we have $p-1$ lags in $\Delta y$. This approach considers several specifications of the VECM - (a) the unrestricted trend assumption puts no restrictions on the parameters thus assuming quadratic trends in the levels of the variables and that the cointegrating equations are stationary around time trends ; (b) the restricted trend assumption $(T=0)$ holds that the levels of the variables show linear trends and that the cointegrating equations are trend stationary; (c) unrestricted constant assumes that the cointegrating equations are stationary around constant means but it also puts a linear time trend (i.e., $T=0$ and $\rho=0)$; (d) restricted constant assumes that the cointegrating equations are stationary around constant means and that there are no linear time trend in the level of the variables (i.e., $T=0$ and $\rho=0$ and $\gamma=0$ ); and (e) no trend assumes that there are no trend and the cointegrating equations are stationary around zero means (i.e., $T=0$ and $\rho=0, \gamma=0$ and $\mu=0)^{l}$.

\footnotetext{
${ }^{1}$ See Stata User's Guide: http://www.stata.com/manuals13/u.pdf
} 
I have carried out both unrestricted and restricted VECM. The result of the unrestricted model is presented in annex 1. It shows that the co-integrating relationship is significant at $1 \%$ level (chi sq=49.20). It suggests the long run relationship between CPI, M2, and industrial production as follows:

$$
\text { lcpi }=-17.32-0.10 \text { lM2 + } 1.03 \text { lipro }-0.001 t
$$

$$
\text { (0.098) (0.176) }
$$

According to equation (5), we see that a $1 \%$ increase of the money multiplier is associated with a monthly decline of the CPI index by $0.10 \%$ (i.e., $1.2 \%$ decline annually) in the long run. It is somewhat puzzling that an increasing money supply is associated with decline in inflation; however, the result is not statistically significant at conventional level. We also see that a $1 \%$ increase in the industrial production is associated with an equivalent $1.03 \%$ increase in monthly CPI, and is statistically significant at 5\% level. Thus it can be said that the impact of money supply is not significant but the impact of output growth is significant on inflation in the long run. The result of the VECM suggests that every after one month, $1.1 \%$ of the deviation from the long run equilibrium is restored (see Annex 1).

I have compared among different specifications of the restricted VECM based on the Likelihood Ratio (LR) statistics. While comparing between two different specifications, a low LR ratio implies that the new specification is better than the previous specification. Accordingly, I have found that the model with the unrestricted constant is a better specification (see results in Table 4).

Table 4: Results of comparison between different specifications of the VECM

\begin{tabular}{llll}
\hline Comparing models & LR chi2 & Prob $>$ chi2 & Decision \\
\hline 'trend' vs. 'rtrend' & 3.82 & 0.1482 & 'rtrend' is a better specification than 'trend' \\
'rtrend' vs. 'constant' & 0.18 & 0.6685 & 'constant' is better than 'rtrend' \\
'constant' vs. 'rconstant' & 25.52 & 0.0000 & 'constant' is better than 'rconstant' \\
'constant' vs. 'none' & 26.60 & 0.0000 & 'constant' is better specification than 'none' \\
\hline
\end{tabular}

Notes: 'trend', 'rtrend', 'constant', 'rconstant', and 'none'stand for the 'unrestricted trend', 'restricted trend', 'unrestricted constant', 'restricted constant', and 'no trend' respectively.

I re-estimate the restricted VECM in terms of the unrestricted constant specification. The result of the model is shown in annex 2 . The result shows that the co-integrating relationship is highly statistically significant at $1 \%$ level (chi sq=1266.3). The co-integrating relationships are estimated as follows -

$$
\text { lcpi }=-13.89-0.14 l M 2+0.87 \text { lipro }
$$

The result suggests that a $1 \%$ increase in the money multiplier associates a $0.14 \%$ decrease in monthly CPI (or $1.7 \%$ decrease annually), which is not statistically significant at $5 \%$ level. It also suggests that $1 \%$ increase in industrial production is associated with $0.87 \%$ increase in the CPI, which is statistically significant at $5 \%$ level. Thus the results support the findings of the unrestricted model which predicts a non-significant impact of money supply but a significant impact of output on inflation in the long run. The result of the VECM tells that every after one month, $1.3 \%$ of the deviation from the long run equilibrium is restored (see Annex 2).

However, the inference of the parameters of our VECM requires

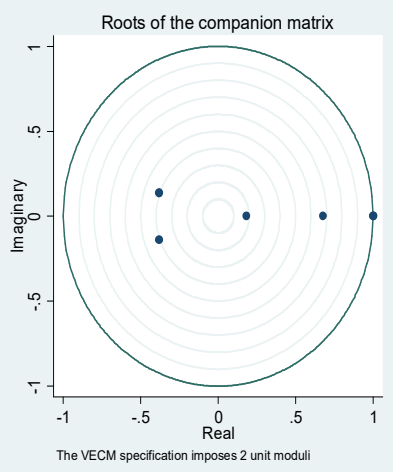
that the model is stationary and that the number of cointegrating equations is correctly specified. The graph of the companion matrix show that that all the eigenvalues are inside the circle (i.e, the values are $<1$; see Annex 3 ). It suggests that the VECM is stable and the model is correctly specified. 


\section{Granger Causality}

Granger causality explains how much of the future values of a variable (say, $y_{t}$ ) can be forecasted by the lagged values of another variable $\left(x_{t}\right)$, after controlling for the influence of the lagged values of the variable itself (Wooldridge 2009). The idea of the Granger causality is to look at the temporal order of events or the direction of the causality - whether $x$ precedes $y$, or the other way round. The Granger Causality test involving two time series variables $Y_{t}$ and $X_{t}$ requires estimation of the following pairs of regression -

$$
\begin{aligned}
Y_{t} & =\sum_{i=1}^{n} \alpha_{i} X_{t-i}+\sum_{j=1}^{n} \beta_{j} Y_{t-j}+u_{t} \ldots \ldots \ldots \ldots(7) \\
X_{t} & =\sum_{i=1}^{n} \lambda_{i} X_{t-i}+\sum_{j=1}^{n} \delta_{j} Y_{t-j}+v_{t} \ldots \ldots \ldots \ldots(8)
\end{aligned}
$$

where $u_{t}$ and $v_{t}$ are assumed to be uncorrelated.. Now we can distinguish four possible cases from these equations - (a) unidirectional causality from $\mathrm{X}$ to $\mathrm{Y}$ when $\sum \alpha_{i} \neq 0$ and $\sum \delta_{j}=0$; (b) unidirectional causality from $\mathrm{Y}$ to $\mathrm{X}$ when $\sum \alpha_{\mathrm{i}}=0$ and $\sum \delta_{j} \neq 0$; (c) feedback or bilateral causality when $\sum \alpha_{i} \neq 0$ and $\sum \delta_{j} \neq 0$; (d) independence when $\sum$ $\alpha_{\mathrm{i}}=0$ and $\sum \delta_{\mathrm{j}}=0$ (Granger 1969; Gujarati et al. 2009). The idea of the Granger Causality can be extended to a system of multivariate VAR model.

I have applied the Granger causality test to see if - (a) money supply Granger causes inflation (or the other way round); (b) industrial production Granger causes inflation (or the opposite); and (c) money supply Granger causes growth (or the opposite). The result of the pair-wise Granger causality test is shown in Table 5. The Wald test statistics suggest that we cannot reject the null hypothesis that money supply does not Granger cause inflation. In contrast, we can reject the null that industrial production does not Granger cause inflation. The statistics also tells that money supply Granger causes growth in industrial production at $1 \%$ level of significance. Thus the result of the Granger Causality test lend support in favour of the findings of the VECM which shows a significant effect of output but a non-significant effect of money supply on inflation. It implies that the monetarist prediction that inflation is a monetary phenomenon does not hold true in Bangladesh. It seems reasonable in the context a developing country like Bangladesh where there are still lots of physical and human capital underutilized. Thus we can say that increased money supply causes economic growth and growth causes inflation in the Bangladesh economy. The Granger Causality result also indicates that inflation and industrial production do not have significant impact on money supply thereby rejecting the possibility of bi-directional causality running from real economic growth to money supply.

Table 5: Result of the Granger Causality Wald test statistics

\begin{tabular}{clcc}
\hline & chi2 & df & Prob>chi2 \\
Excluded & Dependent variable: lcpi & \\
lM2 & 7.1461 & 12 & 0.848 \\
lipro & 24.531 & 12 & 0.017 \\
All & 31.651 & 24 & 0.136 \\
& Dependent variable: $l$ M2 & \\
Excluded & 3.505 & 12 & 0.991 \\
lcpi & 19.439 & 12 & 0.078 \\
lipro & 25.699 & 24 & 0.369 \\
All & Dependent variable: lipro & \\
& & \\
Excluded & 20.496 & 12 & 0.058 \\
lcpi & 34.981 & 12 & 0.000 \\
lM2 & 50.483 & 24 & 0.001 \\
All & &
\end{tabular}

Note: The result is computed at 12 lags 


\section{Conclusion}

In this paper, I have used monthly data to analyze the long run relationship between money supply, inflation, and output growth of Bangladesh. Using the Johansen multivariate technique, I have found that there is one cointegrating relationship among these three variables. Using the Granger Causality technique, I have found that growth of money supply does not cause inflation in Bangladesh. I have found that increased money supply causes outputgrowth in Bangladesh, which rejects the monetarist view of the neutrality of money. However, my findings support another monetarist proposition that the causality is unidirectional from money to economic growth and not vice-versa. All these findings suggest the need for undertaking expansionary monetary policy for maximizing output growth in Bangladesh.

\section{References}

Bannock, G., R. E. Baxter \& E. Davis (2009), The Penguin Dictionary of Economics, Penguin Books.

Barth, J.R. \& J.T. Bennett (1974), "The Role of Money in the Canadian Economy: An Empirical Test", The Canadian Journal of Economics 7 (2), 306-311.

Bhuiyan, R. (2012), "The Effects of Monetary Policy Shocks in Bangladesh: A Bayesian Structural VAR Approach", International Economic Journal 26 (2), 301-316.

Bilquees, F. (1988), "Inflation in Pakistan: Empirical Evidence on the Monetarist and Structuralist Hypothesis", The Pakistan Development Review 27(2), 109-130.

Chowdhury, A. R., M. Q. Dao \& A. N. M. Wahid (1995), "Monetary Policy, Output, and Inflation in Bangladesh: A Dynamic Analysis", Applied Economics Letters 2 (3), 51-55.

Crowder, W.J. (1988), “The Long Run Link between Money, Growth, and Inflation”, Economic Inquiry 36, 229 243.

Engle, R. \& C.W.J. Granger (1987), "Cointegration and Error Correction: Representation, Estimation and Testing”, Econometrica 55, 251-276.

Froyen, R.T. (2005), Macroeconomics: Theories and Policies, $8^{\text {th }}$ Edition, Pearson Education, Inc.

Granger, C.W.J (1969), "Investigating Causal Relations by Econometric Models and Cross-Spectral Methods", Econometrica 37(3), 424-438.

Greene, W.H. (2006), Econometric Analysis , $5^{\text {th }}$ Edition, Pearson.

Gujarati, N. D., D. C Porter \& S. Gunasekar (2009), Basic Econometrics, $5^{\text {th }}$ Edition, New York: McGraw Hill Companies, Inc.

Hossain, A. (2011), "Money-Income Causality in Bangladesh: An Error Correction Approach", Bangladesh Development Studies 34 (1), 39-58.

Johansen, S. (1988), "Statistical Analysis of Cointegrating Vectors", Journal of Economic Dynamics and Control $12,231-54$.

Jones, D. J. \& Z. Sattar (1988), “Money, Inflation, Output and Causality: The Bangladesh Case, 1974-1985”, The Bangladesh Development Studies 16(1), 73-83.

Kemal, M.A. (2006), “Is Inflation in Pakistan a Monetary Phenomenon?”, The Pakistan Development Review 45 (2), 213-220.

Malik, W.S.(2006). "Money, Output, and Inflation: Evidence from Pakistan”, The Pakistan Development Review, 45(4), Part II, 1277-1286.

Mujeri, M. K., M. Shahiduzzaman \& M. E. Islam (2009), “Application of the P-Star Model for Measuring Inflationary Pressure in Bangladesh”, The Bangladesh Development Studies 32 (1), 1-22. 
Rami, G.(2010), “Causality between Money, Prices and Output in India (1951-2005): A Granger Causality Approach", Journal of Quantitative Economics 8 (2), 20-41.

Rangarajan, C. \& R.R. Arif (1990), "Money, Output and Prices: A Macro Econometric Model”, Economic and Political Weekly 25(16), 837-852.

Sims, C.A. (1972), "Money, Income, and Causality”, The American Economic Review 62 (4), 540-552.

Taslim, M. A. (1982), "Inflation in Bangladesh: A Reexamination of the Structuralist-Monetarist Controversy", The Bangladesh Development Studies 10(1), 23-52.

Williams, D., C.A.E. Goodhart \& D.H. Gowland (1976), "Money, Income, and Causality: The UK Experience", The American Economic Review 66(3), 417-423.

Wooldridge, M. J. (2009), “Introductory Econometrics: A Modern Approach”, $4^{\text {th }}$ Edition, Cengage.

\section{Annex 1: Result of the Unrestricted VECM}

Vector error-correction model

Sample: $1995 \mathrm{~m} 8$ - 2009m7

Log likelihood $=1248.49$

$\operatorname{Det}($ Sigma_ml $)=7.04 \mathrm{e}-11$

$$
\begin{array}{ccccc} 
& \text { No. of } & \text { obs. } & = & 168 \\
\text { AIC } & & & = & -14.62488 \\
\text { HQIC } & & = & -14.47395 \\
& \text { SBIC } & & = & -14.25298
\end{array}
$$

\begin{tabular}{|c|c|c|c|c|c|c|c|}
\hline & & Coef. & Std.Err. & $\mathrm{z}$ & $\mathrm{P}>\mathrm{Z}$ & {$[95 \%$} & erval] \\
\hline \multirow[t]{6}{*}{ D_lcpi } & $\begin{array}{l}\text { cel } \\
\text { L1. }\end{array}$ & -0.011 & 0.015 & -0.730 & 0.466 & -0.041 & 0.019 \\
\hline & $\begin{array}{l}\text { lcpi } \\
\text { LD. }\end{array}$ & 0.133 & 0.078 & 1.700 & 0.088 & -0.020 & 0.286 \\
\hline & $\begin{array}{l}\text { 1M2 } \\
\text { LD. }\end{array}$ & 0.006 & 0.017 & 0.350 & 0.727 & -0.027 & 0.038 \\
\hline & $\begin{array}{l}\text { lipro } \\
\text { LD. }\end{array}$ & -0.015 & 0.016 & -0.930 & 0.353 & -0.046 & 0.016 \\
\hline & trend & 0.000 & 0.000 & 1.460 & 0.145 & 0.000 & 0.000 \\
\hline & cons & 0.003 & 0.001 & 2.370 & 0.018 & 0.001 & 0.005 \\
\hline \multirow[t]{6}{*}{ D_1M2 } & $\begin{array}{c}\text { ce1 } \\
\text { L1. }\end{array}$ & -0.012 & 0.065 & -0.180 & 0.860 & -0.139 & 0.116 \\
\hline & $\begin{array}{l}\text { lcpi } \\
\text { LD. }\end{array}$ & 0.023 & 0.333 & 0.070 & 0.946 & -0.629 & 0.675 \\
\hline & $\begin{array}{l}\text { 1M2 } \\
\text { LD. }\end{array}$ & -0.442 & 0.070 & -6.280 & 0.000 & -0.580 & -0.304 \\
\hline & $\begin{array}{l}\text { lipro } \\
\text { LD. }\end{array}$ & -0.103 & 0.067 & -1.530 & 0.126 & -0.235 & 0.029 \\
\hline & trend & 0.000 & 0.000 & -1.290 & 0.195 & 0.000 & 0.000 \\
\hline & cons & 0.009 & 0.005 & 1.660 & 0.096 & -0.002 & 0.019 \\
\hline \multirow[t]{6}{*}{ D_lipro } & $\begin{array}{l}\text { ce1 } \\
\text { L1. }\end{array}$ & 0.384 & 0.072 & 5.300 & 0.000 & 0.242 & 0.526 \\
\hline & $\begin{array}{l}\text { lcpi } \\
\text { LD. }\end{array}$ & -0.490 & 0.370 & -1.320 & 0.186 & -1.215 & 0.236 \\
\hline & $\begin{array}{l}\text { 1M2 } \\
\text { LD. }\end{array}$ & 0.161 & 0.078 & 2.050 & 0.040 & 0.007 & 0.315 \\
\hline & $\begin{array}{l}\text { lipro } \\
\text { LD. }\end{array}$ & -0.213 & 0.075 & -2.850 & 0.004 & -0.359 & -0.066 \\
\hline & trend & $-1.52 \mathrm{e}^{-06}$ & 6.000 & 0.000 & -0.030 & 0.979 & 0.000 \\
\hline & cons & 0.001 & 0.006 & 0.130 & 0.896 & -0.011 & 0.012 \\
\hline
\end{tabular}

\begin{tabular}{|l|c|c|c|c|c|}
\hline Equation & Parms & RMSE & R-sq & chi2 & P $>$ chi2 \\
\hline D_lcpi & 6 & .0076 & 0.3024 & 70.2411 & 0.0000 \\
\hline D_lM2 & 6 & .0324 & 0.2139 & 44.0836 & 0.0000 \\
\hline D_lipro & 6 & .0361 & 0.3237 & 77.5329 & 0.0000 \\
\hline
\end{tabular}


Cointegrating equations

\begin{tabular}{|l|c|c|c|}
\hline Equation & Parms & chi2 & P>chi2 \\
\hline ce1 & 2 & 49.20194 & 0.0000 \\
\hline
\end{tabular}

Identification: beta is exactly identified

Johansen normalization restriction imposed

\begin{tabular}{|c|c|c|c|c|c|c|c|}
\hline & beta & Coef. & Std. Err. & $\mathrm{Z}$ & \multicolumn{2}{c|}{$\mathrm{P}>\mathrm{z}$} & \multicolumn{2}{c|}{$[95 \%$ Conf. Interval] } \\
\hline \multirow{4}{*}{ ce1 } & lcpi & 1 &. &. &. &. &. \\
\cline { 2 - 8 } & lM2 & 0.0997 & 0.0975 & 1.0200 & 0.3060 & -0.0913 & 0.2907 \\
\cline { 2 - 8 } & lipro & -1.0288 & 0.1761 & -5.8400 & 0.0000 & -1.3740 & -0.6836 \\
\cline { 2 - 8 } & trend & 0.0011 &. &. &. &. &. \\
\cline { 2 - 8 } & cons & 17.3150 &. &. &. &. &. \\
\hline
\end{tabular}

\section{Annex 2: Result of the Restricted VECM}

Vector error-correction model

Sample: $1995 \mathrm{~m} 8-2009 \mathrm{~m} 7$

Log likelihood $=1246.489$

$\operatorname{Det}($ Sigma ml $)=7.21 \mathrm{e}-11$

\begin{tabular}{lrr} 
& \multicolumn{1}{c}{ No. of obs } & $=$ \\
AIC & \multicolumn{3}{c}{$=-14.63678$} \\
& HQIC & $=-14.50848$ \\
& SBIC & $=-14.32066$
\end{tabular}

\begin{tabular}{|l|c|c|c|c|c|}
\hline Equation & Parms & RMSE & R-sq & chi2 & P $>$ chi2 \\
\hline D_lcpi & 5 & .00762 & 0.2944 & 68.0042 & 0.0000 \\
\hline D_1M2 & 5 & .03246 & 0.2071 & 42.5776 & 0.0000 \\
\hline D_lipro & 5 & .03608 & 0.3196 & 76.5632 & 0.0000 \\
\hline
\end{tabular}

\begin{tabular}{|c|c|c|c|c|c|c|c|}
\hline & & Coef. & Std.Err. & $\mathrm{Z}$ & $\mathrm{P}>\mathrm{Z}$ & \multicolumn{2}{|c|}{ [95\% Conf. Interval] } \\
\hline \multirow[t]{5}{*}{ D_lcpi } & $\begin{array}{c}\text { cel } \\
\text { L1. }\end{array}$ & -0.013 & 0.018 & -0.750 & 0.450 & -0.048 & 0.021 \\
\hline & $\begin{array}{l}\text { lcpi } \\
\text { LD. }\end{array}$ & 0.149 & 0.078 & 1.900 & 0.057 & -0.004 & 0.301 \\
\hline & $\begin{array}{l}\text { lM2 } \\
\text { LD. }\end{array}$ & 0.004 & 0.017 & 0.270 & 0.789 & -0.028 & 0.037 \\
\hline & $\begin{array}{l}\text { lipro } \\
\text { LD. }\end{array}$ & -0.014 & 0.016 & -0.920 & 0.357 & -0.045 & 0.016 \\
\hline & cons & 0.004 & 0.001 & 5.840 & 0.000 & 0.003 & 0.006 \\
\hline \multirow[t]{5}{*}{ D_1M2 } & $\begin{array}{l}\text { cel } \\
\text { L1. }\end{array}$ & -0.046 & 0.075 & -0.620 & 0.536 & -0.194 & 0.101 \\
\hline & $\begin{array}{l}\text { lcpi } \\
\text { LD. }\end{array}$ & -0.004 & 0.332 & -0.010 & 0.992 & -0.654 & 0.647 \\
\hline & $\begin{array}{l}\text { lM2 } \\
\text { LD. }\end{array}$ & -0.431 & 0.070 & -6.120 & 0.000 & -0.569 & -0.293 \\
\hline & $\begin{array}{c}\text { lipro } \\
\text { LD. }\end{array}$ & -0.117 & 0.067 & -1.760 & 0.078 & -0.248 & 0.013 \\
\hline & cons & 0.004 & 0.003 & 1.150 & 0.249 & -0.003 & 0.010 \\
\hline \multirow[t]{5}{*}{ D_lipro } & $\begin{array}{c}\text { cel } \\
\text { L1. }\end{array}$ & 0.437 & 0.083 & 5.240 & 0.000 & 0.273 & 0.601 \\
\hline & $\begin{array}{l}\text { lcpi } \\
\text { LD. }\end{array}$ & -0.516 & 0.369 & -1.400 & 0.162 & -1.240 & 0.207 \\
\hline & $\begin{array}{l}\text { 1M2 } \\
\text { LD. }\end{array}$ & 0.150 & 0.078 & 1.920 & 0.055 & -0.003 & 0.304 \\
\hline & $\begin{array}{l}\text { lipro } \\
\text { LD. }\end{array}$ & -0.222 & 0.074 & -3.000 & 0.003 & -0.368 & -0.077 \\
\hline & cons & 0.001 & 0.004 & 0.150 & 0.882 & -0.006 & 0.007 \\
\hline
\end{tabular}


Cointegrating equations

\begin{tabular}{|c|c|c|c|}
\hline Equation & Parms & chi2 & P $>$ chi2 \\
\hline ce1 & 2 & 1266.299 & 0.0000 \\
\hline
\end{tabular}

Identification: beta is exactly identified Johansen normalization restriction imposed

\begin{tabular}{|l|c|c|c|c|c|c|c|}
\hline & beta & Coef. & Std. Err. & $\mathrm{Z}$ & \multicolumn{2}{c|}{$\mathrm{P}>\mathrm{Z}$} & \multicolumn{2}{c|}{$[95 \%$ Conf. Interval] } \\
\hline \multirow{4}{*}{ ce1 } & lcpi & 1 &. &. &. &. &. \\
\cline { 2 - 8 } & $\mathrm{lM} 2$ & .1430 & .0668 & 2.14 & 0.032 & .0121 & .2739 \\
\cline { 2 - 8 } & lipro & -.8655 & .0387 & -22.34 & 0.000 & -.9414 & -.7896 \\
\cline { 2 - 8 } & cons & 13.8914 &. &. &. &. &. \\
\hline
\end{tabular}

Annex 3: Eigenvalue stability condition

\begin{tabular}{|c|c|c|}
\hline \multicolumn{2}{|c|}{ Eigenvalue } & Modulus \\
\hline 1 & & 1 \\
\hline 1 & & .675575 \\
\hline .6755747 & $+.138712 \mathrm{i}$ & .405556 \\
\hline-.3810964 & $-.138712 \mathrm{i}$ & .405556 \\
\hline. .3810964 & & .183155 \\
\hline
\end{tabular}

The VECM specification imposes 2 unit moduli 